\title{
The combined effect of controlled atmosphere with ozone and prochloraz treatment on storage life and quality of pomegranate cv. Hicaznar*
}

\author{
Hakan BOLEL iD 1, Mehmet Ali KOYUNCU iD 1, Derya ERBAŞ ${ }^{\text {iD } 1}$ \\ ${ }^{1}$ Isparta University of Applied Sciences, Faculty of Agriculture, Department of Horticulture, Isparta
}

*This study is a part of first author master's thesis. The study was presented as an oral presentation in the $11^{\text {th }}$ International Frutic Symposium (Optimizing Water Use in the Supply Chain of Fresh Produce and printed as a summary).

Alınış tarihi: 17 Nisan 2019, Kabul tarihi: 19 Temmuz 2019

Sorumlu yazar: Mehmet Ali KOYUNCU, e-posta: koyuncu.ma@gmail.com

\begin{abstract}
The combined effects of controlled atmosphere (CA) storage and postharvest ozone treatment on storage life and quality of pomegranate cv. Hicaznar were investigated. Pomegranates were harvested and grouped in three lots. Non-treated first group was used as control. Second group was exposed to ozone (4 ppm) gaseous for $6 \mathrm{~h}$ at $5 \stackrel{\circ}{\circ}$ C. Last group was chemical treatment, dipped into $0.9 \%$ prochloraz solution at $5 \stackrel{\circ}{\circ} \mathrm{C}$ for 10 seconds. After treatments, fruit were stored in CA $\left(5 \% \mathrm{O}_{2}-10 \% \mathrm{CO}_{2}\right)$ conditions at $6{ }^{\circ} \mathrm{C}$ and $90 \pm 5 \%$ relative humidity for 5 months. Weight loss, total soluble solids content, titratable acidity, respiration rate, fruit skin color, decay incidence, chilling injury and sensory evaluation were determined initially and at one month intervals. Fungicide treatment significantly reduced the weight loss and respiration rate of pomegranates. More decay developed on control fruit than those of ozone and fungicide combinations at the end of storage. Ozone and fungicide treatments gave better results in terms of sensory evaluations compared to control group. No chilling injury incidence was recorded in pomegranate during 5 months. As a result, ozone and prochloraz treatments were effective to prolong the storage life and maintain the postharvest quality of Hicaznar pomegranate stored in CA conditions.
\end{abstract}

Key words: Cold storage, Punica granatum, quality, fungicide, ozone
Kontrollü atmosfer ile kombineli olarak kullanılan ozon ve plokloraz uygulamalarının Hicaznar nar çeşidinin depolanma süre ve kalitesi üzerine etkisi

\section{Öz}

Çalışmada derim sonrası kombineli olarak uygulanan ozon uygulaması ile kontrollü atmosferde (KA) depolamanın Hicaznar nar çeşidininin depolama süresi ve kalitesi üzerine etkileri araştırılmıştır. Derimi yapılan narlar 3 gruba ayrılmıştır. Uygulama yapılmayan birinci grup kontrol grubu olarak kullanılmıştır. İkinci gruba 5 ${ }^{\circ}$ C'de 6 s süre ile 4 ppm ozon uygulaması yapılmıştır. Son grup kimyasal uygulama olup, $5 \stackrel{\circ}{\mathrm{C}}$ sıcaklığındaki \%0.9'luk prokloraz çözeltisine 10 saniye süreyle daldırılmıștır. Bütün uygulamalardan sonra meyveler $6{ }^{\circ} \mathrm{C}$ sicaklık ve \% $90 \pm 5$ oransal neme sahip $\mathrm{KA}\left(\% 5 \mathrm{O}_{2}-\% 10 \mathrm{CO}_{2}\right)$ koşullarında 5 ay süre ile depolanmıştır. Depolama başlangıcında ve birer ay ara ile ağırlık kaybı, suda çözünür kuru madde miktarı, titre edilebilir asitlik miktarı, solunum hızı, meyve kabuk rengi, çürüme oranı, üşüme zararı ve duyusal kalite analizleri yapılmıştır. Fungusit uygulaması depolama boyunca narların ağırlık kaybını ve solunum hızını önemli ölçüde azaltmiştır. Depolama sonunda kontrol uygulamasında diğer iki uygulamaya oranla daha fazla çürüme gözlemlenmiştir. Ozon ve kimyasal uygulamaları duyusal özellikler bakımından kontrol grubuna klyasla daha iyi sonuçlar vermiştir. Narlarda 5 aylık depolama boyunca üşüme zararı 
belirtisine rastlanmamıştır. Sonuç olarak derim sonrası ozon ve prokloraz uygulamaları, KA koşullarında Hicaznar nar çeşidinin derim sonrasını kalitesinin korunması açısından etkili olmuştur.

Anahtar kelimeler: Soğukta muhafaza, Punica granatum, kalite, fungusit, ozon

\section{Introduction}

Turkey is one of the major pomegranate producing countries in the world (Bolel, 2017). Pomegranate, grown in temperate climates, is one of the most important fruit species of many tropical and subtropical countries in the world. It is a nonclimacteric fruit and a considerably perishable throughout the period from harvest to consumer table. Postharvest losses of pomegranate, which affect external and internal quality, are still considered remarkable since the weight loss, skin color's discoloration, decay rate and physiological disorders of fruit are high during cold storage (Mirdehghan et al., 2007; Barman et al., 2011; Koyuncu et al., 2019). Pomegranate, with abundant levels of vitamin $\mathrm{C}$, antioxidant and polyphenol compounds, is considered as functional food (Varasteh et al., 2012).

The main fungi results in severe decay in pomegranates after harvest are Botrytis cinerea, Alternaria spp, Aspergillus niger, Colletotrichum gloeosporioides and Cornelia spp (Palou et al., 2013; Kahramanoglu, et al., 2014). The latent spores placed in the fruit calyx during growing season, in general, become visible after harvest and cause high rate losses in cold storage. Nowadays, it is very difficult to long term cold storage of pomegranate without using fungicide applications. Botrytis cinerea, commonly, is controlled by using different postharvest fungicide, but they have a serious threat against human health and the environment even at very low concentrations (Soumya and Bindu, 2012). Naturally, in developed and developing countries, serious objections have occurred against chemical applications. In recent years, natural treatments and storage techniques (such as ozone, edible coating, modified atmosphere packaging, controlled and dynamic controlled atmosphere storage) have been considered alternative solutions for pomegranate storage. Ozone, which has been used as a disinfectant in more than 30 different industry branches in the world for almost 200 years, can be an alternative technique for the cold storage of pomegranate (Graham, 1997). Ozone is an inorganic molecule with the chemical formula $\mathrm{O}_{3}$. It has been evaluated for postharvest disease control and other storage uses for many years; in 2001 it was listed as a secondary direct food additive permitted in food for human consumption (Tzortzakis et al., 2007). Ozone is also known to increase systemic resistance of fruit by controlling decay and increasing antioxidant compounds in grapes (Artes-Hernandez et al., 2003; 2007). The CA rooms are used to retard quality losses such as weight loss, decay rate, firmness etc. and to extend postharvest life of fruit. The effects of ozone gas in combination with CA storage have not been evaluated in pomegranate cv. Hicaznar for maintain fruit quality.

This research aimed to determine the combined effects of CA with ozone and fungicide treatment on the storage life and quality of pomegranate cv. Hicaznar.

\section{Material and Methods}

Pomegranates cv. Hicaznar grown in Fethiye (Muğla) was used as fruit material in this research carried out in 2016. Pomegranates were harvested at commercial harvest stage considering to total soluble solids (TSS) content, titratable acidity (TA), fruit size and shape (Karaçall, 2010). Fruit were transferred immediately to laboratory and then precooled by using cold air. After precooling fruit were divided into three groups. Non-treated first group was used as control group and, second group was exposed to ozone ( $4 \mathrm{ppm}$ ) by ozone generator in a gas-tight cabinet for $6 \mathrm{~h}$ at $5 \stackrel{\circ}{\circ}$. Last group was chemical treatment, dipped into $0.9 \%$ Prochloraz (N-propyl-N-[2-(2,4,6-trichlorophenoxy)ethyl] imidazole-1-carboxamide) solution (at $5{ }^{\circ} \mathrm{C}$ ) for 10 seconds. Fruit, placed on kraft paper, were allowed to dry at $20{ }^{\circ} \mathrm{C}$. After treatments, pomegranates stored at $6{ }^{\circ} \mathrm{C}$ temperature and $90 \pm 5 \%$ relative humidity for 5 months in $\mathrm{CA}\left(5 \% \mathrm{O}_{2}-10 \% \mathrm{CO}_{2}\right)$ room. During cold storage, the following physical and chemical analyses were performed at one-month intervals.

\section{Chemical and physical analysis}

Weight loss: Weight loss of pomegranate was measured based on the initial weight and calculated as percent (\%).

Total soluble solids content and titratable acidity: The TSS of pomegranate juice was determined with a refractometer (Digital-Atago Pocket PAL-1) and expressed as \%. The TA of pomegranate was measured using $10 \mathrm{~mL}$ of juice, which was titrated 
$(\mathrm{pH}$ meter and titrimeter) with $\mathrm{NaOH}$ solution $(0.1$ mol $\mathrm{L}^{-1}$ ) to an end-point $\mathrm{pH}$ of 8 . The acidity of pomegranate was expressed as g $100 \mathrm{~mL}^{-1}$.

Fruit skin color: Fruit skin color was evaluated on the surface of pomegranate with a colorimeter (Minolta Cr 300, Ramsey, NJ, USA). The calibration of color measurement apparatus (Minolta) was performed using an original calibration plate (white). The values were evaluated according to CIE $\mathrm{L}^{*}$ (represents brightness-darkness changing from 0 to 100$), \mathrm{a}^{*}$ (represents the degree of red-green color; $+a^{*}:$ red, $-a^{*}:$ green) and $b^{*}$ (represents the degree of yellow-blue color; $+b^{*}$ : yellow, $-b^{*}$ : blue) system, and chroma $\left(\mathrm{C}^{*}\right)$ and hue angle $\left(\mathrm{h}^{\circ}\right)$ values were calculated the following formula: $\mathrm{h}^{\circ}=\tan ^{-1}\left(\mathrm{~b}^{*} / \mathrm{a}^{*}\right)$, $\mathrm{C}^{*}=\left[\left(\mathrm{a}^{*}\right)^{2}+\left(\mathrm{b}^{*}\right)^{2}\right]^{1 / 2}$ (Koyuncu et al., 2019).

Respiration rate: Respiration rate was determined using a sample of 500-750 g. Fruit samples were weighed in $5 \mathrm{~L}$ airtight jars at room condition (20 $\left.{ }^{\circ} \mathrm{C}\right)$. After 1-2 $\mathrm{h}$ the gas sample was taken from the jars using a gastight syringe and injected into loop of gas chromatographs (GC). Gas measurements were performed in split/splitless (S/SL) of inlet in split mode with valve and fused silica capilar column (GSGASPRO, $30 \mathrm{~m} \times 0.32 \mathrm{~mm}$ I.D., U.S.A). Respiration rate were measured by Agilent model (6890N) GC using thermal conductivity detector (TCD). The

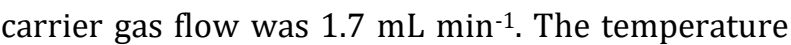
of oven was chosen as $40{ }^{\circ} \mathrm{C}$ (isothermal). The temperature of the TCD was $250{ }^{\circ} \mathrm{C}$. Results were calculated as $\mathrm{mL} \mathrm{CO}_{2} \mathrm{~kg}^{-1} \mathrm{~h}^{-1}$ (Koyuncu et al., 2019).

Sensory analysis: The sensory evaluation panel consisted of 7 members of the research staff (Horticulture Department) who were experienced in sensory analysis of fruit. Pomegranate (coded with three-digit numbers) were served at room temperature and analyzed under fluorescent light in a sensory evaluation room. External appearance and flavor (contribute to the overall quality evaluation) were used key sensorial characteristics by panelists. The hedonic scale was used for external appearance and flavor.

External appearance (scale 1-9): poor quality:1-4; marketable quality: $\geq 5$; good quality: 7-8; excellent quality: 9.

Flavor (scale 1-5): very poor:1; poor: 2; mild: 3; good: 4; excellent: 5 .

Decay and physiological disorders: The fruit taken from storage at one month-intervals were visually checked, and the number of decayed ones was recorded. The number of decay fruit at the end of the each storage period was calculated as $\%$ according to following formula:

Decay rate $(\%)=($ Decayed fruit $) /$ Total number of fruit) $\times 100$

Physiological disorders were determined according to Selçuk (2012).

Statistical analysis: The completely randomized design (with three replications) was chosen for this experiment. Using software package (SPSS, v.16.0), the general linear model (GLM) was used for statistical analyses. The differences among means (at a significance level of 0.05 ) were analyzed using Tukey test.

\section{Result and Discussions \\ Weight loss}

Weight loss of fruit is a very important commercial parameter for storage as it directly refers to the decrease in product weight. Water loss from the skin of pomegranate, which has high porosity, affects visual quality of fruit (Selçuk and Erkan 2013). Weight loss of all treated pomegranate increased significantly in parallel with increasing storage period (Figure 1). The lowest weight loss was obtained from CA + ozone (5.55\%) combination, which was followed by CA + prochloraz (5.98\%) and $\mathrm{CA}+$ control $(7.17 \%)$ at the end of the storage. It is thought that the permeability of skin may be limited by high dose ozone treatment because of its strong oxidant characteristic. Nowadays ozone is practically used in many sectors due to its high oxidant capacity, and because it is much more effective than chlorine and some other antimicrobial agents (Xu, 1999; Horvitz and Cantalejo, 2014). In the present study, weight loss of fruit reached to critical level of $5 \%$ at the $4^{\text {th }}$ month of storage (Figure 1). Similarly, Nerya et al. (2006) found more than 5\% weight loss in pomegranates stored in controlled atmosphere room for 5 months. However, in general, when the long term storage for pomegranate is taken into consideration, the results of weight loss in our study are consistent with the literature findings (Kirpi, 2010; Selçuk, 2012; Öz et al., 2015).

\section{Respiration rate}

It is known that low temperature and CA conditions (low $\mathrm{O}_{2}$ and high $\mathrm{CO}_{2}$ ) decrease respiration rate of horticultural products during cold storage. At present study, the respiration rate of pomegranates was suppressed by the combinations of both CA+ozone and CA+prochloraz compared to 
$\mathrm{CA}+$ control. The initial high respiration rate $(26.23$ $\mathrm{mL} \mathrm{CO} \mathrm{kg}^{-1} \mathrm{~h}^{-1}$ ) decreased rapidly, especially ozone and prochloraz treated fruit, in the first month of storage and remained at the same levels in the rest of the storage (Figure 1). The positive effects of ozone and prochloraz treatments on respiration rate can be attributed the antimicrobial effects of them. Ozone is also known to increase systemic resistance, which can reduce respiration process in cell, of fruit by increasing antioxidant compounds in fruit (ArtesHernandez et al., 2003, 2007). In accordance with our results, Erkan and Pekmezci (1997) reported that storage conditions such as low temperature, low $\mathrm{O}_{2}$ and high $\mathrm{CO}_{2}$ are effective in suppressing respiration rate in pomegranates.
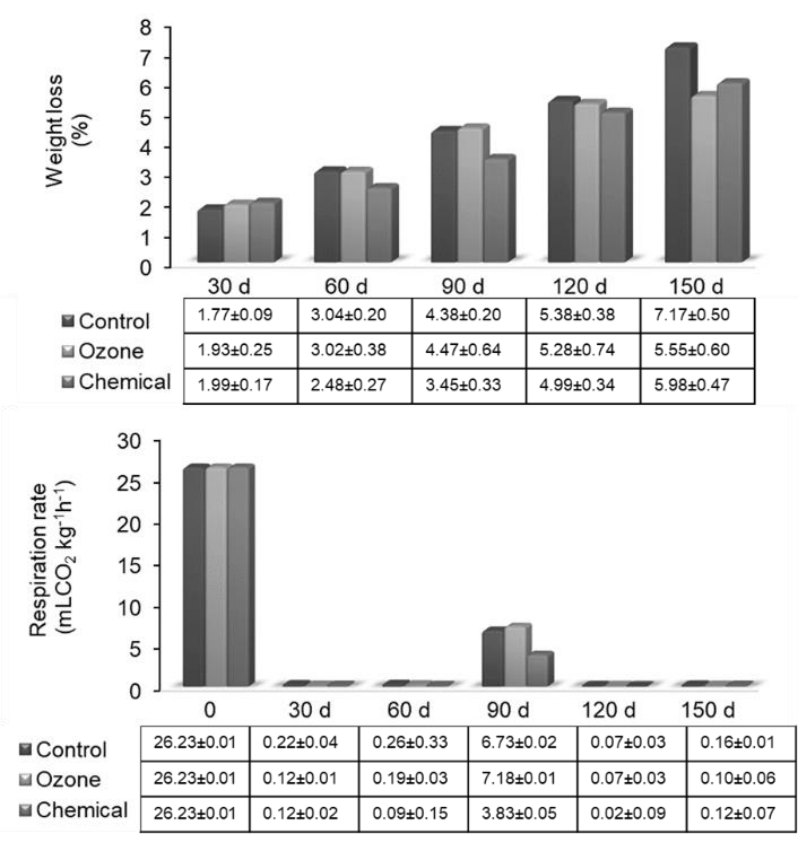

Figure 1. Weight loss and respiration rate of pomegranate cv. Hicaznar during controlled atmosphere storage. Values are mean \pm standard error of triplicate determinations $(\mathrm{n}=3)$.

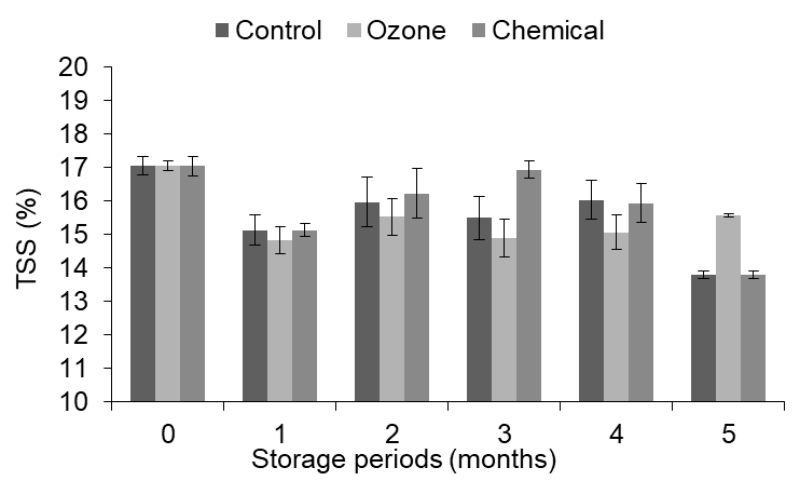

\section{Total soluble solids content}

The effect of the treatments on the TSS content was not significant, while the effect of storage time was found to be significant (Table 1). The TSS contents of all treated pomegranates slightly fluctuated during storage and decreased compared to initial value at the end of storage. The decrease in the TSS values of fruit treated with ozone was relatively higher (15.4\%) than prochloraz (15.8\%) and control (15.6\%) application (Figure 2). As expected, the decrease in TSS content of the Hicaznar pomegranate during the storage is thought to be due to the use of sugars in respiration process. Similarly, Elyatem and Kader (1984) reported that the TSS contents of pomegranates decreased in parallel with the storage period due to respiration process in fruit. On the other hand, it is know that, the weight loss of pomegranates during storage is not directly from the pomegranate arils, but from the fruit skin. Hence, the TSS increase as a percentage cannot be attributed to weight loss of fruit (Nanda et al., 2001).

\section{Titratable acidity}

The effects of both storage period and treatments on these decreases were significant (Table 1). The

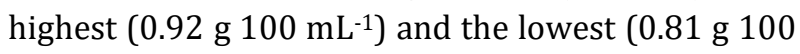
$\mathrm{mL}^{-1}$ ) acidity were obtained from fruit treated with ozone and prochloraz, respectively, according to average values (Figure 2). Similar decreases in acidity of pomegranate throughout the cold storage period were reported by Waskar et al., (1999), Artes et al., (2000), Şen and Eroğul, (2012) and Oğuz et al., (2014). It is desirable to keep TA values of pomegranates close to the initial values during cold storage (Selçuk, 2012). According to this point of view, the combination of CA and ozone treatment gave promising results for TA.

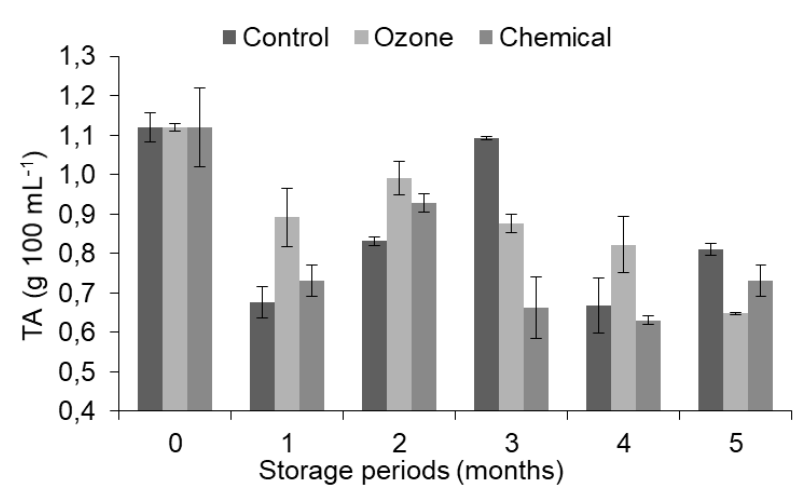

Figure 2. Soluble solids content (TSS) and titratable acidity (TA) of pomegranate cv. Hicaznar during controlled atmosphere storage. Vertical bars represented the standard error of the mean $(n=3)$. 


\section{Fruit skin color}

The changes in $\mathrm{L}^{*}, \mathrm{C} *$ and $\mathrm{h}^{\circ}$ values of skin color during storage are given in Figure 3 . The effect of the treatments on the change of $\mathrm{L}^{*}$ value, which represents the brightness, was significant (Table 1). There were not much variations, except for control, in the average $L^{*}$ values of pomegranates at the end of the storage as compared with initial values. The $\mathrm{L}^{*}$ value of control group decreased from 57.60 to 53.70 , indicating a loss of brightness associated with browning. The best treatment was prochloraz followed by ozone to maintain skin brightness of fruit during storage. It is thought that the oxidant property of ozone was restricted by low oxygen in CA (5\%). Similarly, Artes et al. (1996) found that the $\mathrm{L}^{*}$ values of pomegranate fruit remained same levels or increased slightly in controlled atmosphere room.

The effects of both treatments and storage time on $\mathrm{C}^{*}$ and $\mathrm{h}^{\circ}$ values were significant (Table 1 ). The $\mathrm{C}^{*}$ values, in general, decreased with increasing storage period, while $\mathrm{h}^{\circ}$ values increased and reached the values changing between $37.30^{\circ}$ (prochloraz) and $49.00^{\circ}$ (ozone) at the end of 150 days. The highest average $C^{*}$ value, represents vivid color, was obtained from prochloraz treatment throughout the storage time. This can be explained by that the pomegranates treated with prochloraz lost less weight (Figure 3) and maintained, relatively, quality compared to other applications. It was reported that pomegranates lost their vivid skin color, depending on water loss from skin, after long term cold storage (Selçuk, 2012; Selçuk and Erkan, 2013). As can be seen from Figure 3 , the $h^{\circ}$ values of skin color were higher in ozone treated fruit than those of other treatments. This might be due to the oxidant effect of ozone, which discolored the skin red color of pomegranates. In accordance with present results, Bayram (2007) and Kirpi (2010) indicated increases in $\mathrm{h}^{\circ}$ values of pomegranates during cold storage.
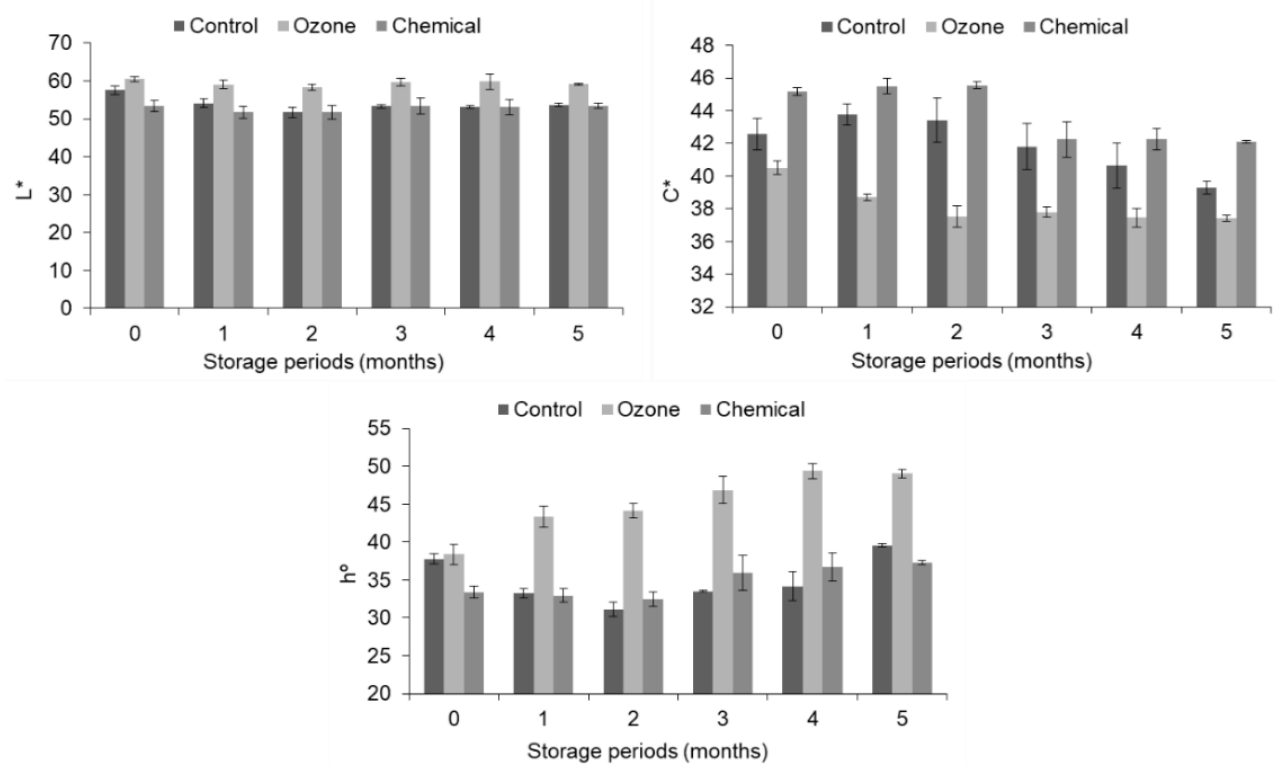

Figure 3. Fruit skin color $\mathrm{L}^{*}$, chroma $\left(\mathrm{C}^{*}\right)$ and hue angle (hํ) value of pomegranate $\mathrm{cv}$. Hicaznar during controlled atmosphere storage. Vertical bars represented the standard error of the mean $(n=3)$.

\section{Sensory analysis}

Significant differences were observed in taste and external appearance of pomegranates throughout storage (Table 1). Panelists gave high scores for external appearance (above 7, except for ozone) and taste (above 4) until the third month of cold storage, and then sensory quality scores decreased depending on treatments in the rest of storage. The higher average scores for both external appearance and taste were obtained from prochloraz treatment, which maintains quality of pomegranates by controlling many fungi. The taste and external appearance scores of pomegranates decreased with storage time in all treatments, however ozone and prochloraz treated pomegranates maintained marketable scores (above 5 and 3) after 150 days cold storage. Control groups had the lowest sensory quality scores (6.25 and 2.50) at the end of storage 
(Figure 4). Similarly, Kirpi, (2010) indicated that control pomegranates (cv. Hicaznar) gave the lowest quality scores in all treatments during cold storage. The Wonderful pomegranates could be stored for 4 months in CA room after fungicide treatments (Nerya et al., 2006). In this trial, ozone, which is applied as an alternative to chemical, was promising treatment compared to control. It can be used for the storage of pomegranates, especially organic ones, but not long term storage.

\section{Decay and physiological disorders}

The effects of both storage period and treatments on decay rates were significant (Table 1). It was not determined any decay incidence on pomegranates until fourth month of storage, but decay rates in ozone treated and control fruit were $13.33 \%$ and $7.62 \%$, respectively, after 5 months cold storage. Prochloraz treatment was very remarkable with zero decay incidence throughout whole storage period. Nerya et al. (2006) found that pomegranates stored in CA room maintained their quality better than air storage. On the other hand, it is known that long term (5-6 months) storage of pomegranate in good quality without fungicide is very difficult.

The physiological disorder in pomegranates such as chilling injury and scald were not recorded during storage.
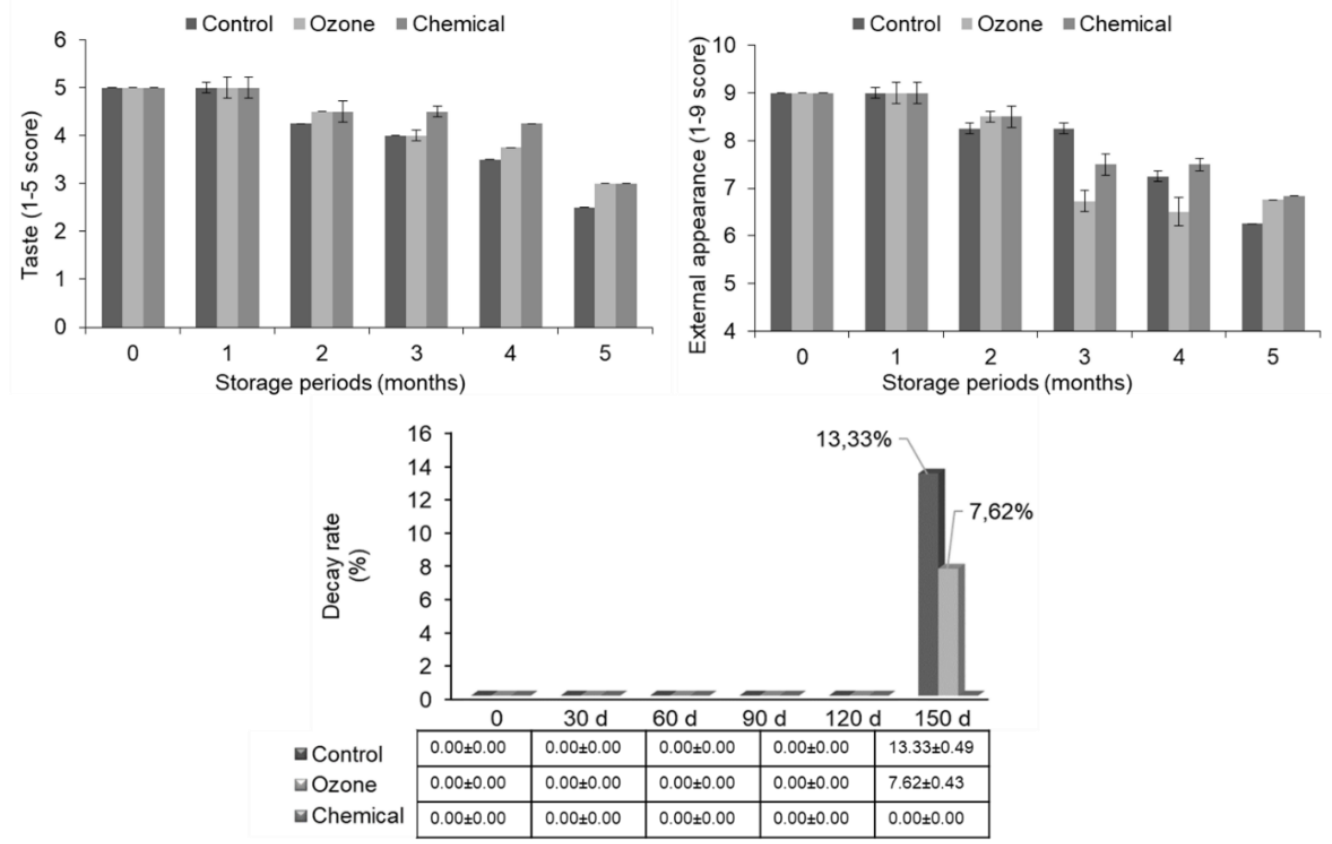

Figure 4. External appearance, taste and decay rate of pomegranate cv. Hicaznar during controlled atmosphere storage. Vertical bars represented the standard error of the mean $(n=3)$. Values are mean \pm standard error of triplicate determinations $(n=3)$. External appearance scale, 1-9 ( $\leq 1-4$ : poor, $\geq 5$ : marketable, 7-8: good, 9: excellent); Taste scale, 1-5 (1: very poor, 2: poor, 3: mild, 4: good, 5: excellent).

Table 1. Anova for dependent variables for treatments, storage period and their interactions

\begin{tabular}{lccc}
\hline Parameters & Storage period (SP) & Treatments (T) & SP $\times \mathrm{T}$ \\
\hline Weight loss (\%) & $* *$ & $\mathrm{~ns}$ & $\mathrm{~ns}$ \\
Respiration rate $\left(\mathrm{mLCO}_{2} \mathrm{~kg}^{-1} \mathrm{~h}^{-1}\right)$ & $* *$ & $\mathrm{~ns}$ & $\mathrm{~ns}$ \\
TSS (\%) & $* *$ & $*$ & $\mathrm{~ns}$ \\
TA $\left(\mathrm{g} 100 \mathrm{~mL}^{-1}\right)$ & $* *$ & $* *$ & $\mathrm{~ns}$ \\
$\mathrm{~L}^{*}$ & $\mathrm{~ns}$ & $* *$ & $\mathrm{~ns}$ \\
Chroma & $* *$ & $* *$ & $*$ \\
Hue angle & $* *$ & $*$ & $* *$ \\
External appearance (1-9 score) & $* *$ & $* *$ & $\mathrm{~ns}$ \\
Taste (1-5 score) & $* *$ & $* *$ & $* *$ \\
Decay rate (\%) & $* *$ & & \\
\hline
\end{tabular}

Ns represents non-significance at $\mathrm{p}<0.05$; ${ }^{* *}$ represents significant at the 0.01 level; ${ }^{*}$ represents significant at the 0.05 level. TSS: Total soluble solids, TA: Titratable acidity 


\section{Conclusions}

Ozone and prochloraz treatments gave promising results for sensory evaluations compared to control group during CA storage of pomegranate. Prochloraz treatment had very remarkable results with zero decay incidence during whole storage period. According the decay rate and sensory evaluation, phlochloraz and ozone treated fruit, and control group can be stored for 5, 4-5 and 4 months with good quality in CA, respectively. As a result, the combination of CA with ozone gaseous or prochloraz was effective to extend the storability of Hicaznar pomegranate compared to control group. As a nonphytotoxic and effective gaseous, ozone could be a promising tool to extend postharvest life of pomegranate.

\section{References}

Artes, F., Marín, J. G., Martínez, J. A., 1996. Controlled atmosphere storage of pomegranate. Zeitschrift für Lebensmittel-Untersuchung und Forschung, 203 (1): 33-37.

Artes, F., Tudela, J. A., Villaescusa, R., 2000. Thermal postharvest treatments for improving pomegranate quality and shelf life. Postharvest Biology and Technology, 18 (3): 245-251.

Artes-Hernandez, F., Artes, F., Tomas-Barberan, F. A., 2003. Quality and enhancement of bioactive phenolics in cv. Napoleon table grapes exposed to different postharvest gaseous treatments. Journal of Agricultural and Food Chemistry, 51 (18): 52905295.

Artes-Hernandez, F., Aguayo, E., Artes, F., Tomas-Barberan, F.A., 2007. Enriched ozone atmosphere enhances bioactive phenolics in seedless table grapes after prolonged shelf life. Journal of the Science of Food and Agriculture, 87 (5): 824-831.

Barman, K., Asrey, R., Pal, R. K., 2011. Putrescine and carnauba wax pretreatments alleviate chilling injury, enhance shelf life and preserve pomegranate fruit quality during cold storage. Scientia Horticulturae 130 (4): 795-800.

Bayram, E., 2007. Değişik Ambalaj Tiplerinin Hicaznar Çeşidinin Soğukta Muhafazası Üzerine Etkileri. Çukurova Üniversitesi Fen Bilimleri Enstitüsü (Basılmış), Yüksek Lisans Tezi, Adana, 63 s.

Bolel, H., 2017. Ozon Uygulanmıș Narın Kontrollü ve Modifiye Atmosfer Koşullarında Depolanması. Süleyman Demirel Üniversitesi Fen Bilimleri Enstitüsü (Basılmış), Yüksek Lisans Tezi, Isparta, $64 \mathrm{~s}$.
Elyatem, S. M., Kader, A. A., 1984. Post-harvest physiology and storage behaviour of pomegranate fruits. Scientia Horticulturae, 24 (3-4): 287-298.

Erkan, M., Pekmezci, M., 1997. Meyvelerde solunum ve solunuma etki eden faktörler. Akdeniz Üniversitesi, Ziraat Fakültesi Dergisi, 10 (1): 261-273.

Graham, D. M., 1997. Use of ozone for food processing. Food Technology, 51 (6): 72-75.

Horvitz, S., Cantalejo, M. J., 2014. Application of ozone for the postharvest treatment of fruits and vegetables, Critical Reviews in Food Science and Nutrition, 54 (3): 312-339.

Kahramanoglu, İ., Usanmaz, S., Nizam, I., 2014. Incidence of heart rot at pomegranate fruits caused by Alternaria spp. in Cyprus. African Journal of Agricultural Research, 9 (10): 905-907.

Kirpi, N., 2010. Derim Sonrası Sıcak Su Uygulamasının Hicaznar Çeşidinde Muhafaza Kalitesi Üzerine Etkisi. Çukurova Üniversitesi Fen Bilimleri Enstitüsü (Basılmış), Yüksek Lisans Tezi, Adana, 63 s.

Koyuncu, M. A., Erbaş, D., Onursal, C. O., Secmen, T., Guneyli, A., Uzumcu, S. S., 2019. Postharvest treatments of salicylic acid, oxalic acid and putrescine influences bioactive compounds and quality of pomegranate during controlled atmosphere storage. Journal of Food Science and Technology, 56 (1): 350-359.

Mirdehghan, S. H., Rahemi, M., Martínez-Romero, D., Guillen, F., Valverde, J. M., Zapata, P. J., Serrano M., Valero, D., 2007. Reduction of pomegranate chilling injury during storage after heat treatment: role of polyamines. Postharvest Biology and Technology, 44 (1): 19-25.

Nanda, S., Sudhakar, R. D. V., Krishnamurthy, S., 2001. Effects of shrink film wrapping and storage temperature on the shelf life and quality of pomegranate fruits cv Ganesh. Postharvest Biology and Technology, 22 (1): 61-69.

Nerya, O., Gizis, A., Tsvilling, A., Gemarasni, D., Sharabi-nov, A., Ben-Arie, R., 2006. Controlled Atmosphere Storage of Pomegranate. Acta Horticulturae, 712: 655-660.

Oğuz H. İ., Şen F., Eroğlu D., 2014. Güneydoğu Anadolu Bölgesinde farkli lokasyonlarda yetiştirilen 'Katırbaşı' nar (Punica granatum L.) çeşidinin depolanma süresince bazi fiziksel ve biyokimyasal içeriklerindeki değişimlerin belirlenmesi. Yüzüncü Yıl Üniversitesi Tarım Bilimleri Dergisi, 24 (3): 309-316.

Öz, A. T., Kafkas E., Zarifikhosrofhahi, M., Şahin, T., 2015. 'Hicaznar' çeșidinde farkli uygulamalarin soğukta 
muhafaza süresince fitokimyasal ve uçucu aroma bileșimine etkileri. Türk Tarım-Gıda Bilim ve Teknoloji Dergisi, 3 (5): 235-241.

Palou, L., Taberner, V., Guardado, A., del Río, M. A., Montesinos-Herrero, C., 2013. Incidence and etiology of postharvest fungal diseases of pomegranate (Punica granatum cv. Mollar de Elche) in Spain. Phytopathologia Mediterranea, 52 (3): 478-489.

Selçuk, N., 2012. Farklı Asitlik Seviyelerinde Narlarda Sıcak $\mathrm{Su}$ ve Modifiye Atmosferde Paketleme Uygulamalarının Antioksidan Bileșikler ve Muhafaza Üzerine Etkileri. Akdeniz Üniversitesi Fen Bilimleri Enstitüsü (Basılmış), Doktora Tezi, Isparta, $343 \mathrm{~s}$.

Selçuk, N., Erkan, M., 2013. Modifiye atmosferde muhafazanin Canernar-1 narlarının antioksidan aktivitesi ve derim sonrasi fizyolojisi üzerine etkileri. Akdeniz Üniversitesi Ziraat Fakültesi Dergisi, 26 (2): 81-87.

Soumya, S. L., Bindu, R. N., 2012. Antifungal efficacy of Capsicum frutescens $\mathrm{L}$. extracts against some prevalent fungal strains associated with groundnut storage. Journal of Agricultural Technology, 8 (2): 739-750.

Şen, E., Eroğul, D., 2012. Adıyaman ilinde yetiştirilen 'Hicaznar' nar çeşidinin depolama süresince kalite değişiminin belirlenmesi. Süleyman Demirel Üniversitesi Ziraat Fakültesi Dergisi, 7 (2): 103111.

Tzortzakis, N., Singleton, I., Barnes, J. 2007. Deployment of low-level ozone-enrichment for the preservation of chilled fresh produce. Postharvest Biology and Technology, 43 (2): 261-270.

Varasteh, F., Arzani, K., Barzegar, M., Zamani, Z., 2012. Changes in anthocyanins in arils of chitosan-coated pomegranate (Punica granatum L. cv. Rabbab-eNeyriz) fruit during cold storage. Food Chemistry, 130 (2): 267-272.

Waskar, D. P., Khedkar, R. M., Garande V.K., 1999. Effect of post-harvest treatments on shelf life and quality of pomegranate in evaporative cool chamber and ambient conditions. Journal of Food Science and Technology, 36 (2): 144-117.

Xu, L., 1999. Use of ozone to improve the safety of fresh fruits and vegetables. Food Technology, 53 (10): 58-63. 